UDC 621.039

A. Smychok,

V. Gerliga, DSc, Prof.,

V. Zaporozhan, PhD,

M. Panchenko,

Y. Fylonych

SE "Scientific and Technical Center" GC “NAEGC” Energoatom”, 1 Shevchenko Ave. 1, Odessa, Ukraine, 65044; e-mail: a.smychok@ntc.atom.gov.ua

\title{
EXPERIMENTAL FACILITY FOR THE STUDY OF THE PROCESSES IN MIXING LOW-PRESSURE HEATERS OF K-1000-60/3000 TURBINES
}

А.А. Смичок, В.А. Герлига, В.В. Запорожан, М.А Панченко, Ю.В. Филонич. Експериментальний стенд для вивчення процесів, що протікають в змішувальних підігрівачах низького тиску турбоустановок К-1000-60/3000. Розвиток атомної енергетики сьогодні визначається рішенням комплексу науково-технічних проблем, що забезпечують надійність та безпеку діючих та проектованих АЕС. При цьому аналізуються різні аварійні ситуації, можливість (ймовірність) найрізноманітніших відмов у роботі обладнання. Досвід експлуатації змішувальних підігрівачів низького тиску (ПНТ) на ТЕС та АЕС показує, що на деяких режимах роботи турбоустановки в ПНТ-2 виникають пульсації, що призводить до руйнування внутрішніх елементів ПНТ-2 та порушенню в роботі трубопроводів обв'язки. В свою чергу, це негативно відображається на роботі обладнання яке знаходиться за ПНТ-2, по ходу руху конденсатно-живильного тракту. На відновлення цих порушень в конструкції ПНТ витрачається певний час та матеріальні ресурси, знижується коефіцієнт використання встановленої потужності блоку та економічні показники. У доповіді представлено проект конструкції лабораторного стенду та опис основних конструктивних особливостей його компонентів. Стенд розроблений з метою вивчення процесів, що призводять до появи вібрацій у змішувальних підігрівачах низького тиску конденсатно-живильного тракту турбоустановок К-1000-60/3000. Основним завданням, при «масштабному» моделюванні, $\epsilon$ необхідність дотримання еквівалентних умов протікання тепло-гідравлічних процесів у моделі по відношенню до натурного обладнання. Для вирішення даного завдання, засобами коду ANSYS, було виконано попереднє розрахункове моделювання гідравлічних процесів, що відбуваються в стенді. Це дозволило заздалегідь визначити певні конструктивні особливості при проектуванні зазначеного стенду. Результати експериментальних досліджень, розробленого стенда, мають дозволити розробити заходи щодо зниження рівня або цілковитого усунення вібрацій у змішувальних ПНТ, а також провести валідацію розрахункових комп'ютерних програм з розрахункового аналізу стаціонарних і нестаціонарних тепло-гідравлічних процесів в зазначеному обладнанні та апробації розроблених заходів.

Ключові слова: експериментальний стенд, змішувальні ПНТ, нестійкі режими, AEC, ANSYS

A. Smychok, V. Gerliga, V. Zaporozhan, M. Panchenko, Y. Fylonych. Experimental facility for the study of the processes in mixing low-pressure heaters of K-1000-60/3000 turbines. Nowadays, the development of nuclear energy is determined by solving the set of scientific and technical problems that provides reliable, safe and sustainable work of the operated and designed NPPs. At the same time different accident conditions and likelihood (probability) of variant equipment operating failures are analyzed. Obtained operating experience of the mixing low-pressure heaters (LPH) at thermal power plants (TPP) and NPPs shows that pulsations occur in some operation regimes of LPH turbine which lead to inner element destructions of LPH and pipeline malfunctions. These circumstances negatively affect operation of equipment that locates after LPH in condensate-supply tract. Consequently, unit capacity factor and economic indicators descend since troubleshooting for LPH mechanisms require some time and material resources. This work presents the experimental facility design and description of main design features of the facility components. The stand was designed to study the processes that lead to the vibration appearance in mixing LPH in condensate-supply tract of K-1000-60/3000 turbines. The main task of scale modeling is the need to observe equivalent conditions of the thermal-hydraulic processes behavior in the model in relation to full-scale equipment. To solve this problem using ANSYS code a preliminary simulation of hydraulic processes occurring in the experimental facility was performed. This allowed to determine in advance certain design features in the design of given facility. The results of experimental studies of the developed facility should allow to develop measures for reduction or complete elimination of vibrations in mixing $\mathrm{LPH}$, as well as to validate computer programs for design analysis of stationary and non-stationary thermal-hydraulic processes in the specified equipment and designed measures testing.

Keywords: vibration, experimental facility, low-pressure heater, unstable regimes, NPP, ANSYS

\section{Introduction}

Obtained operating experience of the LPH at TPP and NPPs shows that pulsations occur in some operation regimes of mixing LPH-2 (MLPH-2) which lead to inner element destructions of LPH. Unit capacity factor and economic indicators descend since troubleshooting for LPH mechanisms require

\section{DOI: 10.15276/opu.2.61.2020.05}

(C) 2020 The Authors. This is an open access article under the CC BY license (http://creativecommons.org/licenses/by/4.0/). 
some time and material resources. In addition, as a result of violations of the airtightness of the strap pipeline, air intakes occur in the inner volume of the heater that works under discharge which lead to efficiency reduction in its operation and power unit as a whole.

As it was noted by the council of chemical experts from National Nuclear Energy Generating Company of Ukraine "Energoatom", the electrical conductivity increase of steam generator (SG) blow-down water at the units № 3 and № 4 of the Rivne Nuclear Power Plant (RNPP) was due to elevated concentration of organic acids that are ethanolamine decomposition products. It was established that one of the reasons of elevated concentration of organic acids is increased percentage of $\mathrm{O}_{2}$ in condensate tract. It was also noted that the concentration of $\mathrm{O}_{2}$ after LPH-5 at the units № 3 and № 4 of RNPP is $1.5 \ldots 2$ times higher than the value at similar units (with high-speed turbines) of other NPPs of Ukraine. This difference is a result of unknown cause.

It can be assumed that the oxygen content change in the turbine condensate occurs within boundaries of mixing LPH-1 and LPH-2, since the oxygen concentration behind the condenser is within the normal range and other LPHs are surface type and operate under pressure that exceeds atmospheric pressure.

Prelaunch leak checks show impermeability of the mixing LPHs, considering that turbine power below $50 \%$ leads to unstable operation of the mixing LPHs, which leads to vibrations. It can be assumed that loss of integrity of the equipment occurs during power ascension. As a result, the mixing LPH works with air infiltration. Thus, to determine the causes of high oxygen content in the turbine condensate it is necessary to analyze the operation of the mixing heaters.

With reference of before-mentioned information, the stability issues of the mixing low-pressure heaters are relevant and important for increase of power unit efficiency.

\section{Literature data analysis}

Obtained operating experience of the mixing LPH of high-speed turbines at Russian and Ukrainian NPPs shows that in some modes of operation of the turbine there is a certain instability in a pipeline area that connects MLPH-1 and MLPH-2 and water-hammer effect occurs. Inspection results for MLPH-2 during scheduled-preventive maintenance (SPM) confirm above mentioned instability.

During SPM of the 3rd unit of Yuzhnoukrainsk NPP (YNPP) in 1990 partial destructions of the upper perforated sheet and the upper part of steam-distributing box were detected. As stated in the act of internal inspection, the cause of these destructions was water-hammer effect in area of the water chamber that occurs as a result of nonuniformity flow distribution of condensate during its movement from the water chamber to the upper perforated sheet.

A case of similar MLPH-2 damage was previously recorded at the unit №3 of RNPP. Cracks were formed on the upper horizontal sheet and a small section of the sheet dropped down. The same problems in the operation of MLPH-2 are present at Khmelnytskyi NPP (KNPP).

To explain and identify the reasons that negatively affect the operation of mixing LPHs with unstable modes a research by scientific research institute of NPP was performed "Development of a mathematical model of dynamical modes of mixing LPH of K-1000-60/3000 turbines" (Odessa, 2005) [1]. This work examines processes that occur in MLPH-2. Performed by this time computational and experimental studies on improving of a scheme of low-pressure regeneration with mixing LPHs are related to new mixing heaters that are being developed [2]. As for the causes of instability, papers [1, $3-5$ ] provide a detailed overview of the main mechanisms associated with the occurrence of these phenomena, as well as a description of experimental and analytical studies.

The purpose of the work is to create a laboratory facility in compliance with the requirements on the thermal-hydraulic processes behavior of full-scale MLPH-2, which will allow to experimentally examine and identify areas of thermal-hydraulic instability that lead to the destruction of thermalhydraulic equipment elements of NPP and to develop recommendations for elimination of their negative effects and following testing on the specified facility.

\section{Formulation of the problem and research data}

Mixing LPHs are objects that require special sophisticated diagnostic procedures. As experience has shown, the variety of processes in this equipment and its structural and technological features determine the possibility of the development of non-stationary thermal-hydraulic processes. In order to 
study and identify these processes, a facility is required to reproduce the operation of the mixing heater. Thus, principle of operation of MLPH-2 should be considered.

MLPH-2 presented on (Fig. 1) consists of a horizontal cylindrical body and a condensate accumulator.
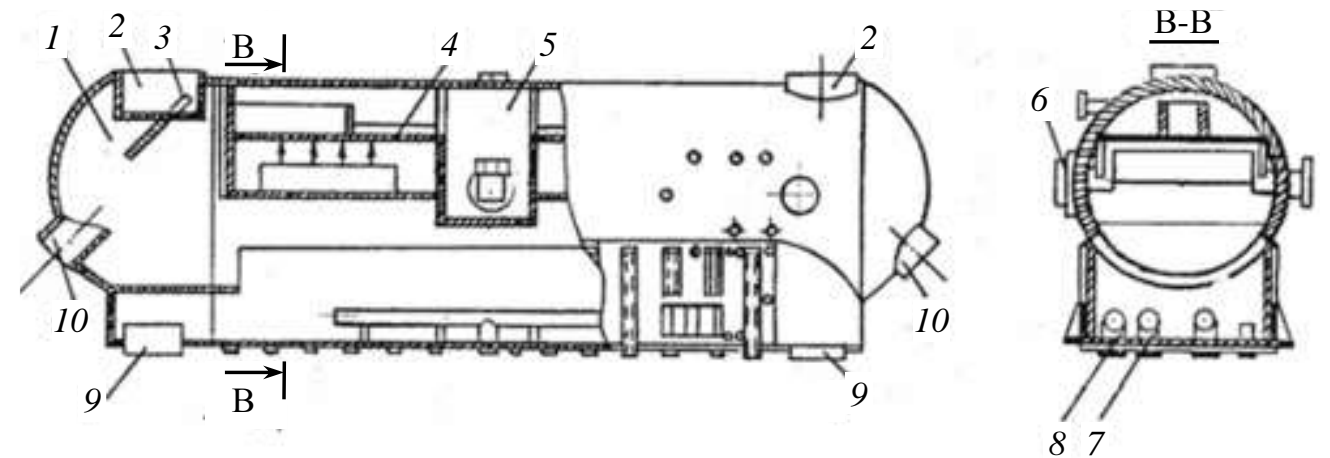

Fig. 1. Structural layout of MLPH-2 for K-1000-60 / 3000 turbines: 1 - steam chamber; 2 - heating steam supply; 3 - reverse closure; 4 - block of perforated plates; 5 -water chamber; 6 -water inlet; 7 -water from calorifiers; 8 - condensate supply of LHP-3 heating steam; 9 - heated water outlet;

10 - emergency overflow branch

The main heat exchange in MLPH-2 occurs due to the steam condensation on the jets of water and partially heat exchange occurs on the plane of saturation. Flow motion pattern of heating steam and condensate which is being heated in MLPH-2 is shown on (Fig. 2).

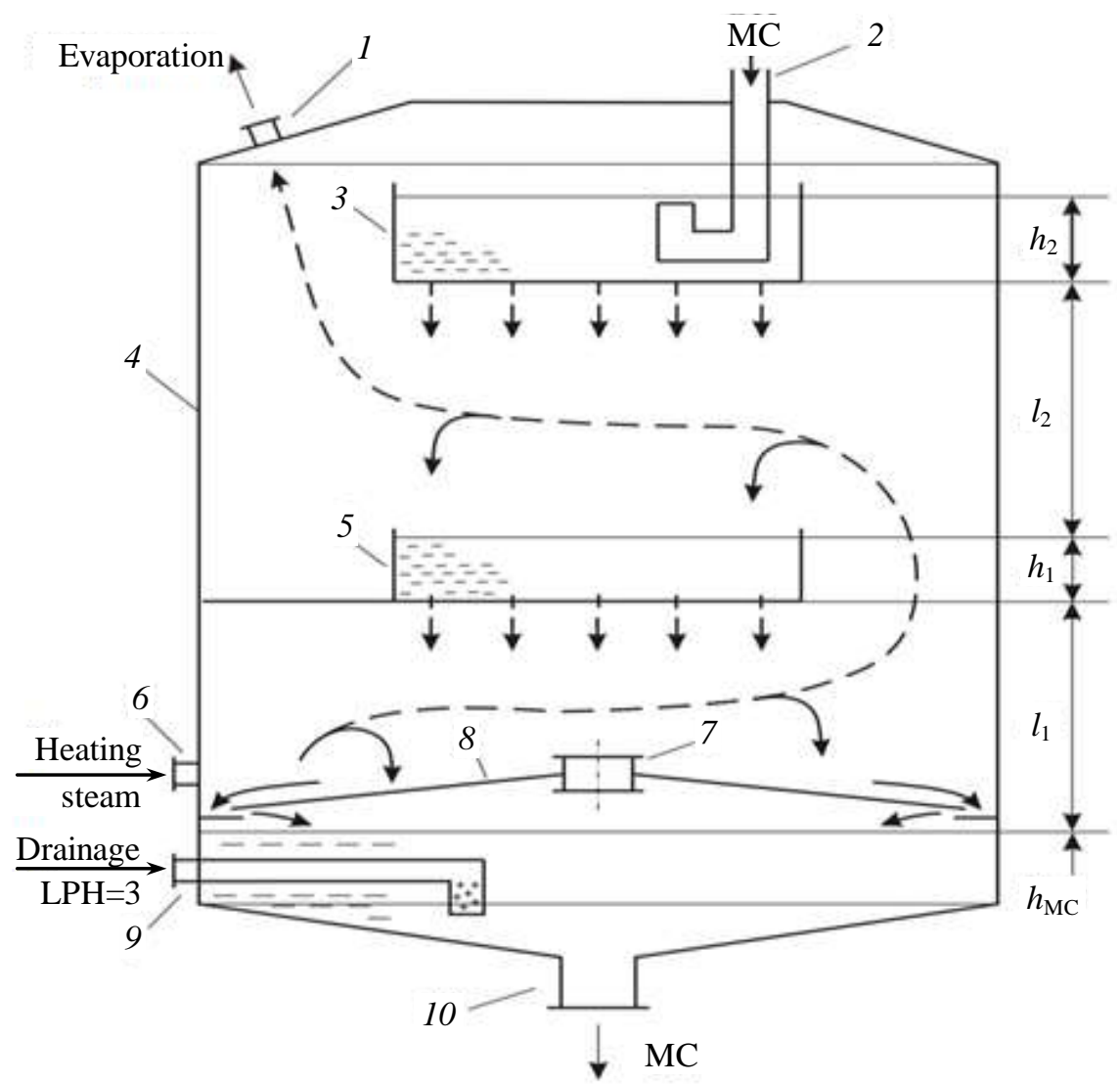

Fig. 2. Computational model for mathematical description of processes in MLPH-2: 1 - evaporation outlet branch; 2 - condensate (MC) supply pipeline from $\mathrm{LPH}-1 ; 3$ - the upper perforated sheet (plate); 4 - LPH-2 body; 5 - the lower perforated sheet (plate); 6 - heating steam supply branch; 7 - outlet vent of drainage evaporation of the next LPH; 8 - shield; 9 -drainage supply branch of the next LPH; 10 - MC outlet branch 
Perforated plates are used to arrange the jet cells in MLPH-2. In the cylindrical part of the heater body two plate blocks are symmetrically located and consist of upper and lower plate intended to fragmentate water on jets. The blocks are connected by a common water intake chamber. Water from the upper plate falls to the lower one. The water level on the plates is maintained by the pressure difference above and below the plates and hydraulic resistance of the perforation.

Drainage from LPH-3 enters the condensate accumulator of MLPH-2 where it partially evaporates due to the pressure drop and the part that has not evaporated gives heat to the turbine condensate and mixes with it. Drainage evaporation mixes with heating steam supplied to the heater from the turbine heat removal.

Then the heating steam from the inlet vapor volume passes under the lower plate where it partially condenses on the jets of water and carries off heat, then enters the intermediate vapor volume, where it is rotated and directed to the jets of water of the upper plate. The major portion of the incoming steam condenses on the jets of the upper plate and heats the main condensate (MC). Noncondensable gases and noncondensable vapor (evaporation) enter the outlet steam chamber from under the upper plate. Evaporation and noncondensable gases are sent to the MLPH-1 via the evaporation pipeline.

According to the purpose of the work the task was to create a facility that mimics processes identical to the full-scale MLPH-2. Although the facility body is rectangular in contrast to the cylindrical body of the full-scale MLPH-2, the water jets geometry is maintained in real dimensions, i.e. it is assumed that the facility will represent part of the heater. At the moment, the work is underway to create the mentioned experimental facility, the experimental facility design is presented on (Fig. 3).

Facility specification (Fig. 3). Heating steam comes from the steam generator (SG) to regulate steam flow capacity in the pipe on which the steam moves, the control valve (CV1) is installed, a throttle washer (TW1) is located after (CV1) along the steam flow and a differential manometer (DM1) to determine the steam flow rate. Next elements are a reverse valve (RV1) and isolation valves (IV1, IV2) and intended for possibility to isolate one of steam tract lines. Then the steam through (4) enters the inlet vapor volume, passes under the lower plate (3) where it partially condenses on the jets of water and respectively gives off the heat, then enters the intermediate vapor volume where it is rotated and directed to the jets of water of the upper plate (2). Major part of the incoming steam condenses on the jets of the upper plate and heats the condensate respectively. The heated condensate is accumulated in the lower part of MLPH and is bleeding through (5) where it is pumped through the pipeline by circulating pump (H1).

Noncondensable gases and noncondensable vapor (evaporation) enter the outlet steam chamber from under the upper plate. Vapor and noncondensable gases are directed to the vapor outlet (6) that is located in the modular cell cover. Next, vapor and noncondensable gas is evacuated by a control valve (CV2) and vacuum pump (H3), creating rarefaction in the MLPH. Pressure in the MLPH is measured by a pressure transducer (MH1).

Condensate level that has accumulated in the lower part of MLPH is fixed by a glass tube (A1). Isolation valves (IV3 and IV4) are installed for the case of tube deformation.

In this facility, the structure on which the lower perforated sheet is placed is mobile and removable. Such design allows to extend conditions of the condensation experiment. When the lower bowl structure is removed heating steam flow will be carried out in the line $(b)$, where the isolation valve (IV2) will be opened and the isolation valve (IV1) will be closed to deactivate the line ( $a$ ) and heating steam will enter the inlet steam volume through (7).

At the outlet of MLPH there is a flow sensor (G1) and a control valve (P3) for decanting water from the facility. The condensate flow before and after the circulating pump (H1) provides isolation valves (IV5 and IV6) intended for replacement or reconditioning of the pump.

A thermal converter (T1) is located downstream of the condensate and measures the water temperature in the pipeline before the heat exchanger (T2) and after the heat exchanger (AT1) as well as the heat converter (T3) of the heat exchanger (AT1) supplied coolant and (T4) at the pipeline outlet. With the help of the pump (H2) cold water regulated by (CV4) and measured by a flow sensor (G3) is supplied to the heat exchanger (AT1) where it cools condensate that is supplied to the mixing heater 
inlet. The cooling water controlled with the help of (CV5) after the heat exchanger goes to the tank (B3) that supplies SG by means of the pump (H4). Supplied water flow rate is controlled by (G4).

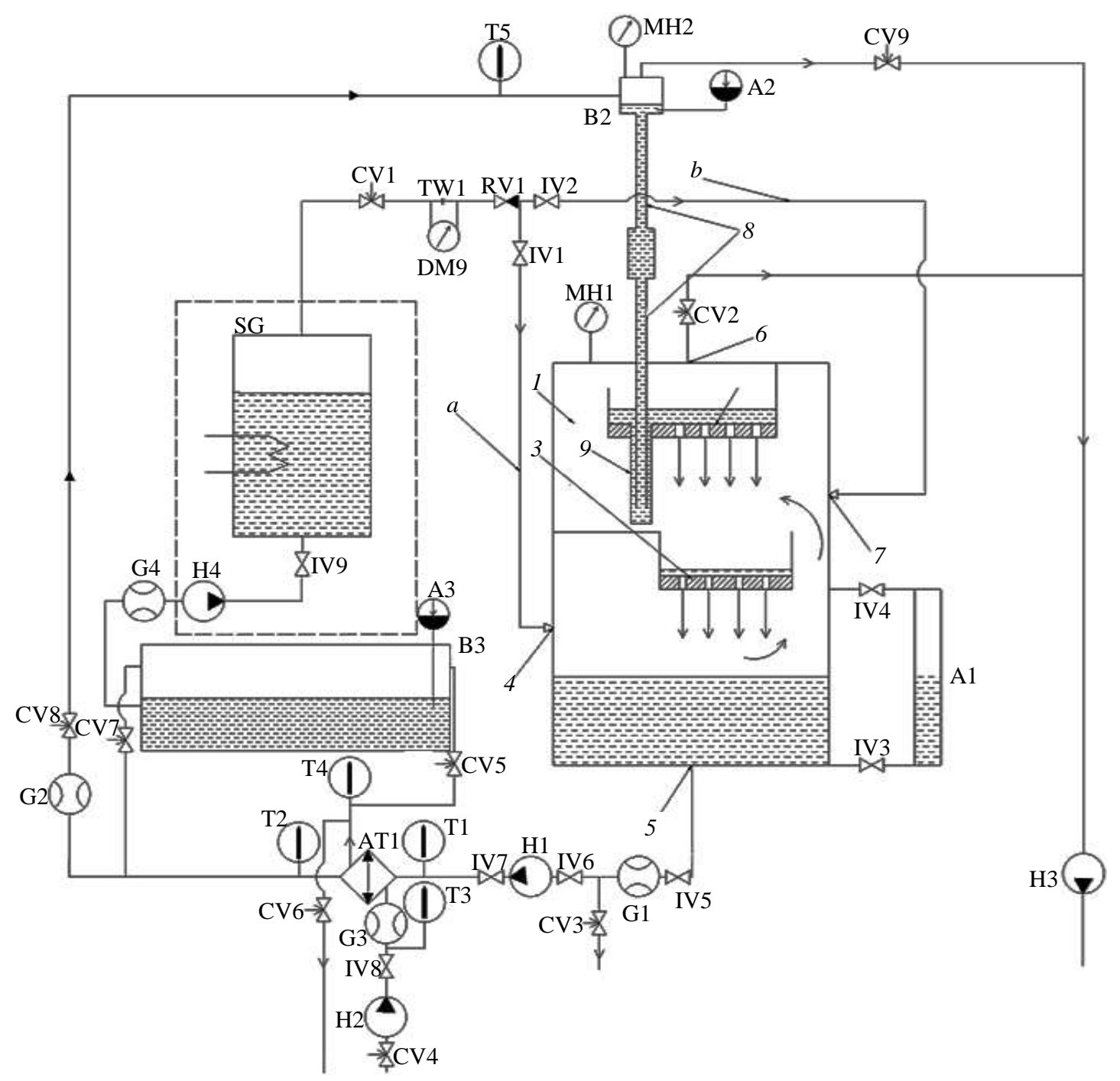

Fig. 3. The experimental facility design for studying the processes in a mixing low-pressure heater: 1 experimental modular section of LPH; 2 - the upper perforated sheet; 3 - the lower perforated sheet; 4 -inlet of the heating steam in the heater (a); 5 -condensate outlet; 6 - evaporation outlet; 7 -inlet of the heating steam in the heater (b); $a, b$-steam tract; 8 -overflow pipe; 9 - hydraulic locking

After the heat exchanger, the control valve (CV7) is located to drain excessive water from the system to (B3). A flow sensor (G2) is located further on the line as well as the control valve (CV8) which controls water flow rate that is supplied to the thermal converter (T5) and measures the water temperature in the pipeline before a tank (B2) inlet. Control valve (CV9) and vacuum pump (H3) create rarefaction in (B2). Pressure in (B2) is measured by a pressure transducer (MH2). A water gage (A2) is used to measure water level in (B2) and down-flow pipe (8). Next, water is supplied to the mixer heater inlet through the down-flow pipe (8) and a tank (B1). Water enters the upper perforated sheet, which creates jet streams, as it passes through the down-flow pipe (8) and hydraulic locking (9).

The experimental modular MLPH is represented as a rectangular body that contains perforated sheets which create steam-heated fluidic water flows. Steam is supplied from the steam generator (SG). Water that is heated by MLPH runs through the heat exchanger (AT1) with the help of pump (H1) where it is cooled and then is supplied back into MLPH inlet. In this way, a closed-loop cycle is created. 
The main heat exchange in MLPH facility proceeds due to the steam condensation on water jets and partial heat exchange occurs on the water table. Upper and lower plates are located inside of rectangular part of the heater body which are intended to divide water on jets. Water is decanted in form of water jets from the upper plate to the lower one. Water level on the plates is maintained by pressure difference between values above and below the plate, and hydraulic resistance of the perforated sheet.

Element design of MLPH was developed to be able to change its configuration, i.e. the elements are movable - height adjustable and replaceable. Such design features allow to extend experimental conditions.

Planned experiments at the facility are part of the work on the development and refinement of the mathematical model of thermal-hydraulic processes occurring in the MLPH in order to study instability. In addition, availability of experimental data obtained on the facility will allow to validate mathematical model of MLPH and corresponding ANSYS model.

In the future it is planned to provide the larger picture of instability emergence mechanism in the MLPH on the basis of experimental studies. It is planned to supplement the known simplified mathematical description of the process that is presented in the report "Development of a mathematical model of dynamical modes of mixing LPH of K-1000-60/3000 turbines" with the following:

- more detailed control and description of hydraulic resistance in liquid and steam tracts;

- description of the processes associated with the possible condensate overflow of perforated sheet edges in pulsation modes;

- control of thermal-hydraulic parameter distribution along the MLPH-2;

- control of impact of process dynamics in MLPH-1 on the stability of MLPH-2 operation.

After compilation of more complete mathematical description of the process in a system, that consists of MLPH-1 and MLPH-2 and the obtained experimental data, it will be developed a mathematical computational model for the analysis of stationary and transient processes that will allow to identify the causes of onset of oscillations with increasing in time amplitude. Furthermore, the mathematical model will allow to develop measures to eliminate unstable modes of operation and to test and adjust these measures on the experimental facility.

\section{Research results}

As it was stated above, the main task of scale modeling is the need to observe equivalent conditions of the thermal-hydraulic processes behavior in the model in relation to full-scale equipment. To solve this problem using ANSYS code a preliminary simulation of hydraulic processes occurring in the experimental facility was performed (Fig. 4).

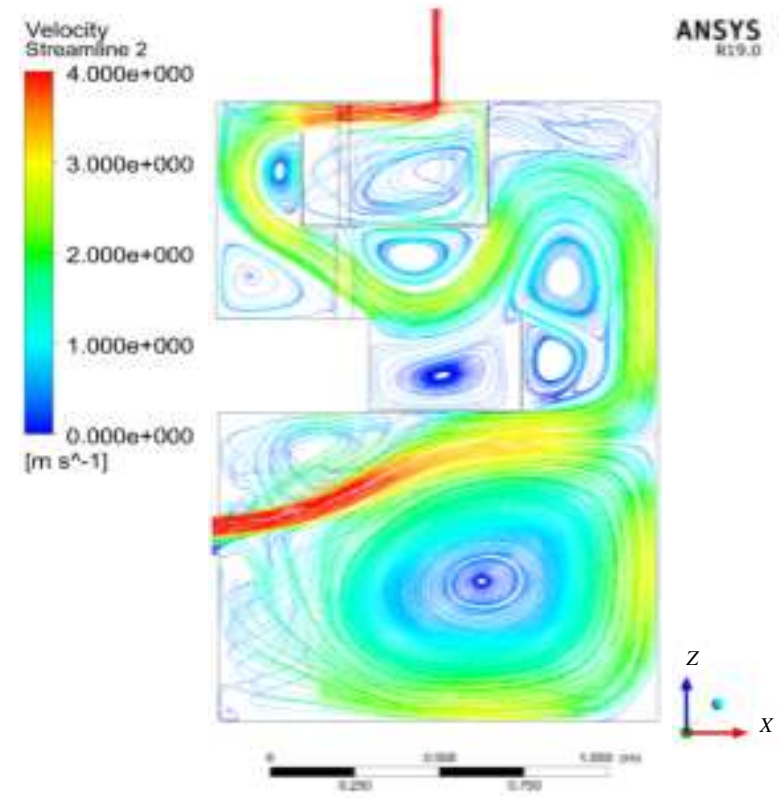

Fig. 4. Steam flows distribution without perforated diffuser nozzle and perforated baffle 
These hydraulic processes influenced the structural features of the facility. For example, a diffuser with perforated nozzle was used for a steam supply branch of the heater body (Fig. 5) and an additional perforated baffle in the flow-through part at the inlet of the lower jet section (Fig. 6).

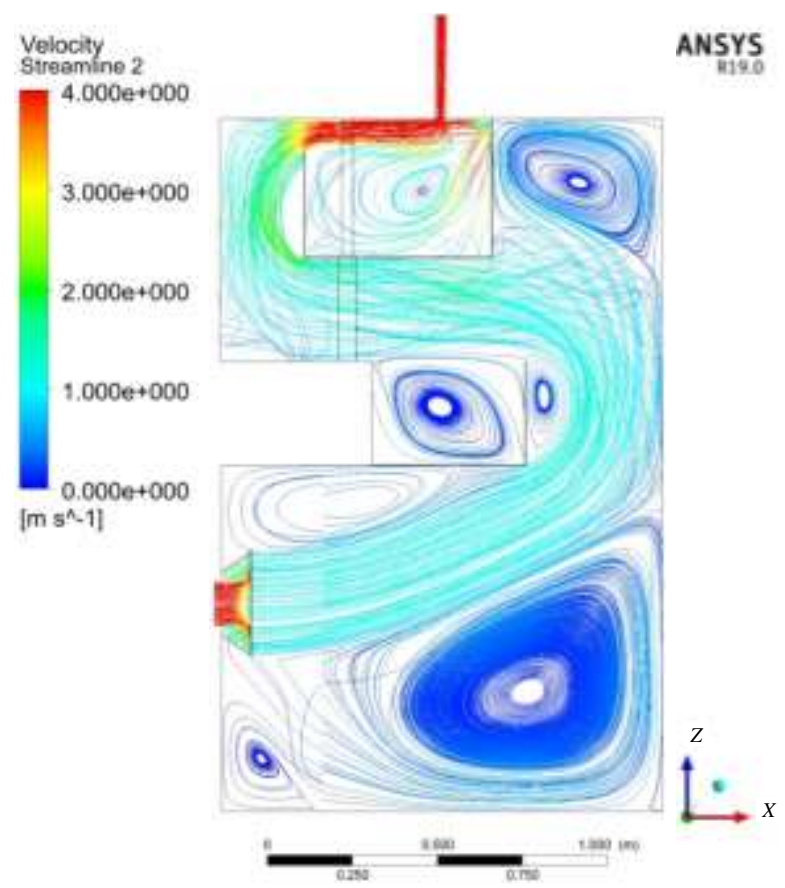

Fig. 5. Steam flows distribution with perforated diffuser nozzle

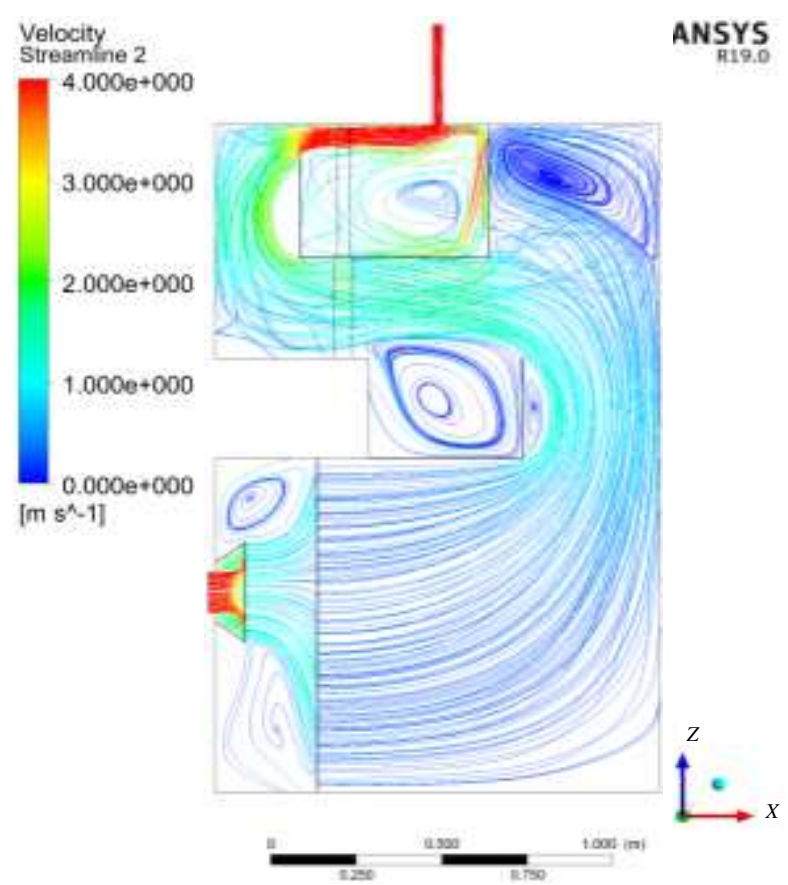

Fig. 6. Steam flows distribution with perforated diffuser nozzle and perforated baffle

Application of perforated diffuser nozzle and perforated baffle caused by the following reasons: - necessity to distribute the steam flow uniformly along the length (height) of the jets;

- necessity to align the velocity profile at the inlet of the jet; 
- necessity to eliminate spurious swirls, stagnant zones, reverse steam flows.

Hereby, steam condensation on the jets is improved and conditions, that approximate processes of real LPH as much as possible, are created.

An assembling drawing of the MLPH body is presented in (Fig. 7).

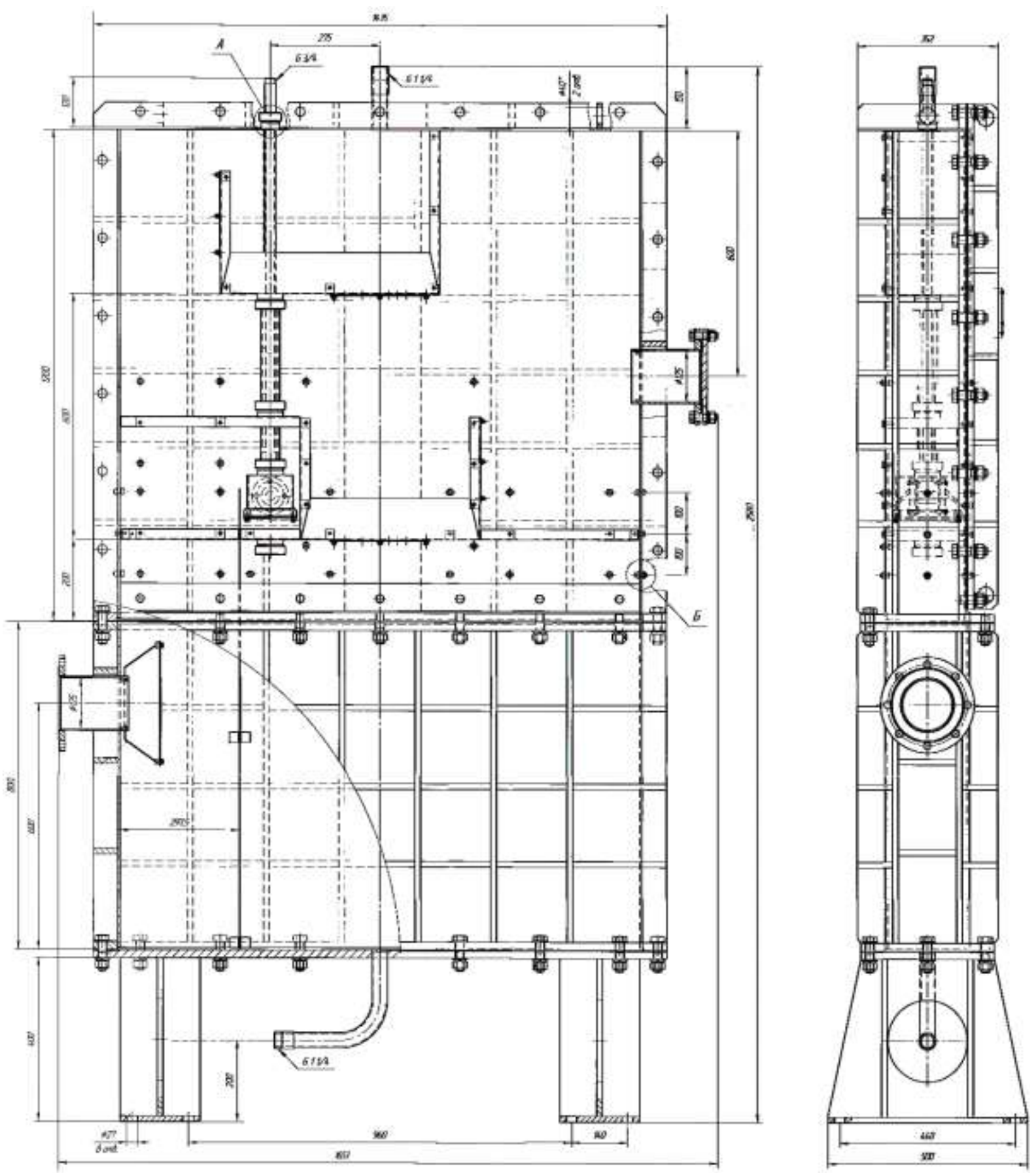

Fig. 7. Assembling drawing for MLPH body

In concert with representatives of engineering and design department of SD "Atomenergomash" sketches for the experimental facility were developed. Next, design documentation will be developed in accordance with these sketches for element production at "Atomenergomash". 


\section{Conclusions}

The facility design was based on certain requirements:

- observance of equivalent conditions of thermal-hydraulic processes flow with full-scale MLPH-2;

- ability to change its configuration to study dependencies on geometric and thermodynamic characteristics;

- ability to record the parameters of the processes that occur in the facility during the experiment.

The experimental facility design will allow to simulate the processes occurring in the MLPH-2. In addition, obtained results of the experiments will allow to verify and validate developed thermalhydraulic models of MLPH-2, which will be used to find measures to eliminate vibrations and unstable operation of the equipment. In particular, the facility will be used to test the developed measures.

Implementation of these measures will be used to increase the efficiency and reliability of operation for the 2nd circuit of NPPs with K-1000-60/3000 turbines.

\section{Література}

1. Khabensky V.B., Gerliga V.A. Coolant Flow Instabilities in Power Equipment. CRC Press, 2017, 388 p.

2. Синцова Т.Г., Трифонов Н.Н., Ермолов В.Ф., Сухоруков Ю.Г. Расчетное и экспериментальное исследование устойчивой работы смешивающих ПНД для ТЭС и АЭС. Вісник НТУ «ХПI». 2014. № 12(1055).

3. Скалозубов В.И., Хадж Фараджаллах Даббах А., Скалозубов К.В. Вопросы теплогидродинамической неустойчивости в оборудовании и трубопроводах АЭС с ВВЭР. Проблеми безпеки атомних електростаниій та Чорнобиля. Вип. 14, 2010.

4. Ruspini L.C., Marcel C.P., Clausse A. Two-phase flow instabilities. International Journal of Heat and Mass Transfer. 2014. 71. 521-548.

5. Vijayan P.K., Nayak A.K. Introduction to Instabilities in Natural Circulation Systems. IAEA Training Course on Natural Circulation Phenomena and Passive Safety Systems in Advanced Water-Cooled Reactors. ICTP. Trieste. Italy, 17-21 May 2010.

\section{References}

1. Khabensky, V.B., \& Gerliga, V.A. (2017). Coolant Flow Instabilities in Power Equipment. CRC Press.

2. Sintsova, T.G., Trifonov, N.N., Yermolov, V.F., \& Sukhorukov, Yu.G. (2014). Computational and experimental study of the stable operation of mixing LPH for TPP and NPP. Bulletin of NTU "KHPÍ», 12(1055).

3. Skalozubov, V.I., Khadzh Faradzhallakh Dabbakh, A., \& Skalozubov, K.V. (2010). Questions of thermohydrodynamic instabilities in WWER NPP equipment and pipelines. Problems of safety of nuclear power plants and Chornobil, 14.

4. Ruspini, L.C., Marcel, C.P., \& Clausse, A. (2014). Two-phase flow instabilities. International Journal of Heat and Mass Transfer, 71, 521-548.

5. Vijayan, P.K., \& Nayak, A.K. (2010). Introduction to Instabilities in Natural Circulation Systems. IAEA Training Course on Natural Circulation Phenomena and Passive Safety Systems in Advanced WaterCooled Reactors, ICTP, Trieste, Italy, 17-21 May 2010.

Смичок Андрій Анатолійович; Smychok Andrii, ORCID: https://orcid.org/0000-0001-9143-1997

Герлига Володимир Антонович; Gerliga Volodymyr, ORCID: https://orcid.org/0000-0002-3627-9475

Запорожан Владислав Володимирович; Zaporozhan Vladyslav, ORCID: https://orcid.org/0000-0003-2573-496X

Панченко Марк Андрійович; Panchenko Mark, ORCID: https://orcid.org/0000-0003-0748-9251

Филонич Юрій Володимирович; Fylonych Yurii, ORCID: https://orcid.org/0000-0003-0748-9251 